\title{
Crime, Justice \& the COVID-19 Pandemic: Toward a National Research Agenda
}

\author{
J. Mitchell Miller ${ }^{1} \cdot$ Alfred Blumstein ${ }^{2}$ \\ Received: 1 July 2020 / Accepted: 1 July 2020 / \\ Published online: 9 July 2020 \\ (C) Southern Criminal Justice Association 2020
}

\begin{abstract}
The novel corona virus COVID-19 has become a worldwide public health pandemic that has induced anomic conditions impacting daily routines. COVID-19 response measures specifically alter regular schedules and both restrict and expand opportunities for various types of crime while presenting unprecedented challenges for the criminal justice system. For criminologists and criminal justice scientists, the virus also presents natural experiment conditions allowing for real-world theory tests and observation of the relative effectiveness of practice and policy options under weighty conditions. Toward synthesizing scientific discourse and forthcoming empirical work, we suggest the benefits of a COVID-19 crime and justice research program and offer some anchoring concepts. Contagion, containment measures (social distancing, facemasks, shelter-in-place, economic shutdown, virtual work and schooling, banned group gatherings), and social ordinance compliance (voluntary or enforced) posture a conceptual framework from which to align research on crime, justice, and victimization during the virus. After observing crime trends and justice system challenges, we suggest how the pandemic presents opportunities for review of various criminal justice, especially incarceration, policies. System change is a recurring theme across this special issue of the American Journal of Criminal Justice that features twenty additional contributions from a wide range of authoritative crime and justice scholars. These articles on traditional crime during the virus, virus specific hate crime and domestic violence, and the challenges posed by COVID-19 to law enforcement, the courts, and corrections will hopefully provide initial commentary toward deeper inquiry.
\end{abstract}

Keywords Contagion · COVID-19 crime $\cdot$ De-carceration $\cdot$ Social ordinances $\cdot$ National research agenda

J. Mitchell Miller

mitch.miller@unf.edu

1 University of North Florida, Jacksonville, FL, USA

2 Carnegie Mellon University, Pittsburgh, PA 15213, USA 


\section{Introduction}

A 2019 novel coronavirus disease (COVID-19) broke out initially in China and spread globally with such speed and dire effects that the World Health Organization declared it a public health emergency of international concern in January of this year (World Health Organization, 2020). COVID-19 attacks the respiratory system more aggressively than other circulating coronaviruses that cause common cold-like illness and presents pronounced health risks of many sorts because there is not yet any pre-existing immunity, available vaccine, or proven treatment. An airborne virus, it spreads easily through human contact and has triggered exponential growth in cases, hospitalizations, and deaths around the globe. The actual extent of the virus can only be estimated as the affected can be contagious during lengthy asymptomatic incubation periods with only mild flu symptoms.

Raging spread has resulted in an ongoing global pandemic that, at the time of writing, has resulted in well over eight million cases and 454,000 deaths worldwide with over two million cases and nearly 130,000 deaths in the United States that certainly will be considerably higher by time this issue is in print. The capacity of countries' health systems to respond to the pandemic, the extent of testing, and reporting transparency vary considerably across (and within) countries so data is more approximate than exact. The virus is truly worldwide and apt to linger over multiple waves with China, Italy, Iran, India, the United Kingdom, and, most recently, Brazil and Russia joining the list headed by the United States as the most plagued nations per Johns Hopkins COVID-19 Dashboard statistics. Not since the Influenza of 1918 has the world experienced such a widespread pandemic, so there is only a minimal experiential reference base to guide an informed response.

As the coronavirus impacts almost every part of public and professional life, social scientists have quickly pivoted to collect real-time data on a vast range of pandemic issues. The effects of limited human contact, contraction anxiety, unemployment, and heightened domestic strife are but a few topics of interest to psychologists and public health researchers; economists have unprecedented disruptions to employment and to supply chains and related market implications to address; and political scientists have "pandemic politics" wherein virtually every government position involves a tradeoff between protecting public health and reinvigorating the economy - a reality only magnified by the media during this election year (Adolph et al., 2020).

For criminology and criminal justice, the new normal of virus life presents a flood of similarly complex choices between protecting public safety and protecting the health of those under control of the criminal justice system as well as those working in it. Most pundits anticipate the virus will drive increases in some types of crime (e.g,, commercial burglary resulting from absenteeism effecting lack of guardianship) while retarding others (e.g., residential burglary per increased home presence and guardianship), that increased domestic violence will ostensibly reflect the limits of social isolation, and that the justice apparatus will be challenged, topics representing but a fraction of crime and justice research foci.

National themed social problems tend to invite quick descriptions of phenomena and fast research conclusions toward crafting solutions. A handful of empirical works, for example, have already reported early data on COVID-19 crime and justice topics (Brantigham, 2020; Payne \& Morgan, 2020; Mohler et al., 2020; and Gerell \& 
Kindgren, 2020), but similar to the time realities of vaccine approval, high quality applied research takes time and ideally employs mixed methods which means qualitative as well as quantitative data collection and analysis usually facilitated through site visits that, per the virus, are largely suspended in general and altogether at detention facilities. This is not to say that early research is wrong, necessarily lacks rigor, or consequence but first look explorations of phenomena do not always represent realities accurately and are typically too limited from which to make strong policy generalizations. In that research shapes policy positions and practices, it is prudent to move forward cautiously rather than invest too heavily on sole studies without replicated result.

Perhaps the most direct impact of the pandemic on the criminal justice system results from the concern over contagion of COVID-19 among the individuals the system controls in prisons and jails. Which arrestees should be sent to jail awaiting trial and which should be released into the community? For people convicted, should they be incarcerated or released on probation? Of people serving time in prison, which ones can be safely released into the community, either because of their high risk if infected or because 4 of their low risk of committing crime on the outside? These decisions of pretrial release, probation, and parole have traditionally been addressed daily, but they could well take a different form in the context of the virus. The concern about contagion puts additional weight favoring release in order to reduce the density in the inevitably crowded prison or jail environments.

\section{Envisioning a National COVID-19 Research Program}

A national COVID-19 research program is needed not only because of its importance in helping to shape effective policy responses to the current version of the coronavirus pandemic, but because it has become clear that it could well change its form in future versions and other pandemics can reasonably be expected to arrive in the future, and the research program can help provide the understanding and insights that are important and necessary for dealing with the pandemic complexities. Toward this end, this introductory discussion identifies some primary concepts central to the development of a potential future pandemic crime and justice research agenda to orient and synthesize directly related forthcoming inquiry toward rigorous scientific discovery and optimal applied practice..

National research programs can be consequential to intelligent policy and practice decisions. In the present case, there is a strong pragmatic and even moral premium on objective science and an empirical knowledge base so that official actions that respond to the virus are not grounded in ideology, partisanship, or selfish economic interests. A research program's conceptual framework sets scope conditions and an orienting strategy that signals, if not directs, the tone of inquiry, actual issues researched, and related attributed significance. Theoretical or national research programs are infrequent in academic criminology and criminal justice with more commentary than actual examples (see Miller, Gibson, \& Byrd, 2008). Rather than resembling more formal theoretical research programs composed of set core and supporting maxims which must be falsifiable (Berger \& Zelditch, 1993) as in related disciplines, criminology and criminal justice research has more loosely employed 
theoretical integration toward research to establish a knowledge base from which to identify, synthesize, and analyze applied issues and challenges.

Justice themed research programs have emphasized the actionable implications of findings from interlocking outcome studies such as Simpson and Sell's series of evaluation research (1982) on the Drug Abuse Reporting Program and the National Institute of Mental Health research agenda organized around conceptual cores of development, classification, and prevention - essentially domains for research conceptualization and design (Reiss \& Price, 1996). Additionally, Huizinga et al., (1995) crafted a research agenda to disentangle the characteristics and arrest histories of chronic delinquents through a typology approach (risk factors identification, violence prediction, developmental pathways interactive effects). More recently, a proposed national research agenda for treatment courts was grounded in inter-twined evidencebased practice, research-practitioner partnership, and mixed-method concepts (Miller et al., 2019). Regardless of subject matter, a commonality across these research programs is specification of core concepts that, collectively, define active and future research questions and agendas.

The virus presents opportunities for real-world theory tests and examination of the justice apparatus under its distinctive conditions, partly to contrast it with otherwise normal conditions and potentially to anticipate what might happen in other pandemic conditions. Leading criminological theories (e.g., routine activities theory, deterrence and rational choice theories, self-control theory, social disorganization, cultural transmission, and social learning perspectives) are of clear relevance to a broad range of both crime and justice COVID related topics. While active justice program evaluations have been compromised by virus-induced disruption of offender treatment protocols indicating program differentiation, linking the virus and criminal justice responses creates natural experiment conditions with comparison groups that otherwise would be impossible to construct - such as offenders receiving early release from incarceration. Although much is yet to be determined regarding the dynamic nature of the virus and findings from virus-related research, a conceptual framework should facilitate discourse and inquiry on the links between the virus and crime and the justice responses.

\section{Core Concepts}

The two foremost focal concepts of the COVID-19 pandemic are contagion and containment. These interrelated ideas posit arenas of case confirmation and reaction around the objective of minimizing contagion and propagation. Shelter-in-place epitomizes the national response of social distancing - a universal mandate of separation, for everyone to stay at home, and prohibition of aggregation of more than a specified number of people (but these vary across and even within states) - thereby canceling sporting events and entertainment events, shutting down restaurants, all "non-essential" businesses, and meetings of all sorts. Stay-home policies and closing of significant portions of the economy has spiked unemployment, social isolation, and competition for basic needs while forcing home schooling and virtual workplaces. Drastically altered daily life due to virus rules and compliance enforcement, ranging from response to defiance of stay-at-home orders and restrictions on public gatherings, and punishment for assault of medical workers usually through coughing, spitting, or sneezing. All 
these have fostered anomalous responses presenting a wide array of situational and global consequences that raise important research questions regarding individual and programmatic effects..

Containment measures, then, are strategies implemented as social ordinances designed to limit transmission of the virus among individuals. There is, unsurprisingly, a great deal of variation in the ways in which different countries, states, and cities have approached the pandemic and the types of containment measures they have employed, and then the timing and type of relief from those measures as the viruses impacts are diminished. Lack of a unified national strategy contributes to the considerable crossstate variation in the initiation and growth patterns of virus severity and of deaths in the United States and in regional variations in virus severity, but without question has resulted in containment measures and their alleviation that vary wildly from state to state and even within states as they and their citizenry vary in their trade-offs between economic recovery and aversion.

Despite containment measures differences, each jurisdiction's response has involved some combination of travel restrictions and border controls, quarantine requirements, social isolation and distancing requirements, and the large-scale closure of various services, business, and educational facilities. While the primary concern of government has been to minimize the health impacts of COVID-19, attention has also turned to the other effects of the pandemic. Government and regulatory interventions include stringent domestic and international travel restrictions and a raft of phased stay-athome and changing social distancing regulations. The scale of these containment measures has left criminologists wondering what impact this will have on various kinds of crime throughout the remainder of the virus and beyond.

Although the federal government has guided social distancing recommendations through semi-regular Centers for Disease Control briefings that have made public health officials Drs. Anthony Fauci and Deborah Birx household names, it has been left to states and cities to implement measures on when to close and when to open different places of business, schools, and public events and local law enforcement agencies to effect compliance. Policy choices can both stimulate or inhibit criminal activity and, in doing so, will thereby generate both intended and unintended consequences, and those effects compared to pre-virus crime should be one focus of future research. Since the virus is not only ongoing but currently spiking in almost half of the states, it is now certain that it will be with us for some time, thereby accentuating the need for empirically informed policy guidance as well as providing the opportunity to develop that guidance.

\section{Crime \& Justice during the Virus}

As the virus has blown up online-virtual life, normal human contact has been largely replaced with intra-family interaction and computerized linkages which have enabled essential government, education, and some business affairs to continue functioning despite the social distancing, but not without consequences. Increased screen time not only elevates exposure to and victimization from already embedded online scams and fraudulent transactions, but also virus-specific cyber-bullying and hate crime through often anonymous social mediums. Social distancing to "flatten the curve" thus impacts 
some routine activities known to condition criminal opportunities and guardianship (Cohen \& Felson, 1979). Lifestyle alterations around contagion threats theoretically should have an impact on the volume and distribution of crime with domestic and family violence correlated with quarantine, economic stress, and increased exposure to harmful relationships during periods of limited support options, perhaps the most obvious crime threat of forced isolation (Usher et al., 2020; Bradbury-Jones \& Isham, 2020). Social distancing should also have an effect in reducing interpersonal violence other than perhaps domestic violence, sex offenses, illicit street markets, and intergang conflicts. More generally, empty streets could well be an indicator of a reduction in the opportunities for conducting robberies, auto theft, and other street crimes and bolster police patrol and surveillance of crime in traditional "hot spot" neighborhoods.

The Police Executive Research Forum (PERF) analyzed crime reports from thirty cities across the United States between mid-March and mid-April of 2020 and compared observations to the same timeframe in 2019 (https:/www.policeforum.org/coronavirus). While the police role in the virus is pronounced and invites obvious research attention to ordinance compliance, domestic violence, the shut-down of the economy has also reduced autonomous revenue generation for law enforcement agencies that fund overtime opportunities (e.g., speeding citations, asset forfeitures, off-duty traffic services, and security services) as all but one place (Prince George County, Maryland) saw fewer calls for service than in 2019. Violent crime generally declined for the most part over the first 100 days of the virus in roughly $60 \%$ of the nation's cities but is now either stable or on the uptake in most places. Robberies and aggravated assault thus far have declined markedly (83\% and 57\%, respectively), $83 \%$ of cities experienced an overall drop in property crime, and there were $43 \%$ less burglaries compared to same months in 2019. As staying home has bolstered online commerce, cybercrime and package theft has increased. Amidst all of this virus crime data to sort out, March and April of 2020 witnessed the highest numbers of gun-related deaths (2100) in the country since 2016 which could well be related to the reports of a significant rise in thefts of guns from gun shops and this could well be related to the reports of a significant rise in thefts of guns from gun shops. As we move deeper into the quarantine and virus life, the crime trend landscape is sure to shift as society attempts to balance re-opening with virus resurgence.

The virus is compelling a range of reactions from law enforcement, the courts, and corrections that also signal research opportunities. In an effort to limit officer exposure to the virus, police departments in several states have begun scaling back arrests for lower level offenses. In order to reduce COVID-19 exposure within their detention facilities, the Nashville Police Department, for example, has already discontinued misdemeanor arrests with the exceptions of domestic violence and drunk driving.

Law enforcement in some places face shortages in personal protective equipment and access to testing while increasingly and somewhat ironically tasked with more virus generated risky work. As more officers contract the virus and agency budgets become strained, some departments will be forced to scale back non-essential services. The Los Angeles Police Department has already closed its front desk to the public in order to ensure distancing and slow the spread. U.S. Customs and Border Protection officials are enforcing new restrictions on travel and commerce along the borders with Canada and Mexico and the Drug Enforcement Administration has had to reprioritize away from traditional investigations to ensure regulated medicines needed to fight the virus are available to their staff and, in turn has loosened restrictions on telemedicine prescription of controlled drugs. 
Federal courts around the United States have closed and delayed trials and most state courts have suspended jury trials, utilized mass plea hearings, and most have pivoted to video proceedings. The impact on jails and prisons in terms of decisions to de-carcerate and whom in terms of risk assessment has probably been the major impact on the CJS, and especially in terms of risk measurement, particularly with long-time older prisoners (usually with excessive mandatory-minimum or life sentences). Tracking various releasees in terms of recidivism represents an opportunity for research that should be included and emphasized more. COVID-19 outbreaks in detention facilities has also moved courts to rethink pre-trial custody and disincentivized custodial sanctions (Skolnik, 2020). The Supreme Court delayed oral arguments for at least a month the longest delay in its proceedings since the 1918 Spanish flu. Prisons and jails have suspended visitation and facility transfers, limited attorney entry, and moved to video for personal visits, legal meetings, and telemedicine. Still, contagion in seemingly super-spreader prisons and jails should remain a constant concern. Pressure on correctional facilities to release offenders is a focal point of a general "de-carcerating" movement (Sivashanker et al., 2020) though it is the courts and probation and parole offices that actually effect release wherein risk assessment is more needed and vital than ever.

\section{Moving Forward}

The dynamic of the response to the pandemic will certainly have an effect on the changing impacts on the criminal justice system. The first phase of the social distancing with a high rate of staying at home is largely ending. As pressure to restore the economy dominates decisions, the threat of resurgence remains. The pressure to reduce contagion in jails and prisons will present natural experiments around early release policies that may demonstrate reconsideration of the incarceration and public safety relationship that, in turn, invites reconsideration of mass incarceration policies more broadly. It is certainly reasonable to anticipate that recidivism rates will be higher in jurisdictions with more risky release practices, but analyses of these and the justice practices and interventions contributing to them, should provide useful indications of where to rethink current incarceration and release policies. The increasing prevalence of long and life sentences (approximately $15 \%$ of the total inmate population) means a large percentage of prison cells are occupied by older and less risky offenders who are reasonable candidates for release to reduce the density of prison population vulnerable to virus contagion. According to the ACLU report "A Living Death: Life Without Parole for Nonviolent Offenses" almost $80 \%$ of the over 3000 people serving life without parole will die in prison from nonviolent drug offense convictions (ACLU Foundation, 2013), certainly a basis for review of such life sanctions resulting from naively presumed deterrence effects (which are undercut by the drug markets recruiting replacements) and retributive arguments for the life sentences for a single serious crime..

The second phase for consideration of the interaction between the pandemic and the criminal justice system will be centered around re-opening as bars and restaurants are opened and travel increased. To some extent, the problem of crime and offenders should begin to return as before, but it will certainly be interesting to see the degree to 
which crime drops noticed during the separation period are erased and to what extent new crimes that emerged continue. Also, one can anticipate somewhat of a reduction in the staffing levels at different parts of the criminal justice system due to the impact of COVID-19, particularly as a consequence of their interactions as part of carrying out their professional responsibilities. As the stress from the virus intensifies over time, mental health issues will likely increase encounters between officers and those with mental disorders that, in turn, will only compound officer resiliency problems.

A third phase that is expected to begin in the mid to late fall of 2020 is the hardest to predict. There is some speculation that the warmth of the summer will diminish the prevalence of the coronavirus, but the cooler weather of the fall will reinitiate the pandemic. One would hope that planning for this phase would involve careful assessment of what went well and what went poorly during the previous two phases and how best to prepare for a reemergence of the pandemic and how to respond to it. It is rather early to guess about that, but it is particularly important to analyze the current phase for lessons in dealing with reemergence spikes. As social distancing and the wearing of facemasks become increasingly challenged, there will no doubt be heavy research focus on public health implications, especially as virus impacts spike up. Understanding the impact of social distancing on crime will also be critical for ensuring the safety of police and government capacity to deal with the lingering crisis and provide insights into whether people are complying with public health measures (Usher et al., 2020).

Of course, we speculate what is to come on the hopeful assumption that the public will proceed with some collective consciousness of public risk and comply with various constraints on re-opening measures. There is ample evidence that many segments of the population largely ignore virus risks and seemingly have little concern about risk to others and ongoing protests over police misconduct, upcoming political rallies, church re-openings and similar congregant events may prompt unpredictable spikes with some states or cities moving forward with re-opening while others may have to backtrack. Over time, virus crime (coughing or spitting and social ordinance violation) and justice (enforcement of ordinances) will become of increasing concern apart from traditional crime during the virus, per se.

It is inevitable that the virus will expose inequalities, vulnerabilities, and related service gaps, attention to the justice system's performance during the pandemic can be extended to more systematic and serious discussions for broader justice policies. Because of contagion issues, the virus warrants reconsideration of the nation's current "mass incarceration rates" that are more than quadruple those that prevailed for at least fifty years (Blumstein and Cohen, 1973) when correctional policies were decided by the functionaries within the criminal justice system rather than today's political messaging to the naïve public that more incarceration inherently lowers crime rates, a presumption contradicted by the failure of the drug war that revealed a labor surplus of willing replacement drug dealers (Blumstein \& Beck, 1999). And those current rates of about 430 prisoners per 100,000 population are still about the highest in the world and declining at a rate of only $1.5 \%$ per year.

We need rigorous research to identify evidence-based approaches and inform challenging policy and practice decisions specific to COVID-19 and virus overlap with the opioid, mental health, and now, racism epidemics. Related, this special issue of the American Journal of Criminal Justice addresses a range of leading crime and justice issues presented by the COVID-19 pandemic. Contributions from several leading 
discipline authorities as well as notable rising scholars will hopefully instigate additional discourse and help frame inquiry strategies as we begin to attempt to understand virus crime and criminal justice response and identify appropriate and effective system behavior.

\section{References}

ACLU Foundation. (2013). A living death: Life without parole for nonviolent offenders. ACLU Publications.

Adolph, C., Amano, K., Bang-Jensen, B., Fullman, N., \& Wilkerson, J. (2020). Pandemic politics: Timing state-level social distancing responses to COVID-19. medRxiv.

Berger, J., \& Zelditch, M. (1993). Theoretical research programs: Studies in the growth of theory. Palo Alto, CA: Stanford University Press.

Blumstein, A., \& Beck, A. J. (1999). Population growth in US prisons, 1980-1996. Crime and Justice, 26, 1761.

Blumstein, A., \& Cohen, J. (1973). A theory of the stability of punishment. Journal of Criminal Law, Criminology and Police Science, 63(2), 198-207.

Bradbury-Jones, C., \& Isham, L. (2020). The pandemic paradox: The consequences of COVID-19 on domestic violence. Journal of Clinical Nursing., 29, 2047-2049.

Brantingham, P. J. (2020). Impact of social distancing during COVID-19 pandemic on crime in Los Angeles and Indianapolis. Journal of Criminal Justice, 101692.

Cohen, L. E., \& Felson, M. (1979). Social change and crime rate trends: A routine activity approach. American Sociological Review, 44, 588-608.

Gerell, M., Kardell J., \& Kindgren J. (2020). Minor covid-19 association with crime in Sweden, a five week follow up. https://doi.org/10.31235/osf.io/w7gka

Huizinga, D., Loeber, R., \& Thornberry, T. P. (1995). Recent findings from the program of research on the causes and correlates of delinquency (a report to NIJ). Washington, DC: Office of Justice Programs.

Miller, J. M., Gibson, C. L., \& Byrd, J. (2008). Getting beyond the liberal feel-good: Toward an accountability-based theoretical research program for restorative justice. In Restorative justice: From theory to practice (pp. 261-278). New York: Emerald Group Publishing.

Miller, J. M., Miller, H. V., \& Miller, B. L. (2019). Envisioning a National Research Program for substance abuse treatment courts. Innovative Approaches for the Treatment Court Field, 5.

Mohler, G., Bertozzi, A. L., Carter, J., Short, M. B., Sledge, D., Tita, G. E., \& Brantingham, P. J. (2020). Impact of social distancing during COVID-19 pandemic on crime in Los Angeles and Indianapolis. Journal of Criminal Justice, 101692.

Payne, J., \& Morgan, A. (2020). Property crime during the COVID-19 pandemic: A comparison of recorded offence rates and dynamic forecasts (ARIMA) for march 2020 in Queensland, Australia.

Reiss, D., \& Price, R. H. (1996). National research agenda for prevention research: The National Institute of Mental Health report. American Psychologist, 51(11), 1109-1115.

Skolnik, T. (2020). Criminal law during (and after) COVID-19. Forthcoming: Manitoba Law Journal.

Sivashanker, K., Rossman, J., Resnick, A., \& Berwick, D. M. (2020). Covid-19 and decarceration. bmj, 369.

Usher, K., Bhullar, N., Durkin, J., Gyamfi, N., \& Jackson, D. (2020). Family violence and COVID-19: Increased vulnerability and reduced options for support. International Journal of Mental Health Nursing. World Health Organization. (2020). (https://www.who.int/emergencies/diseases/novel-coronavirus-2019.

Publisher's Note Springer Nature remains neutral with regard to jurisdictional claims in published maps and institutional affiliations.

J. Mitchell Miller (Ph.D., Tennessee, 1996) is the John A. Delaney Presidential Professor in the Department of Criminology \& Criminal Justice at the University of North Florida where he teaches and conducts research in the areas of criminological theory, drugs and crime, offender programming, and justice program evaluation. He is a Fellow of the Academy of Criminal Justice Sciences and an ACJS Bruce Smith, Sr. and Founders Award recipient, as well as an inductee in the American Society of Criminology Oral History Project. A past president of the Southern Criminal Justice Association, Dr. Miller is the former editor of the Journal of Criminal Justice Education and the Journal of Crime \& Justice and the current Editor of the American Journal 
of Criminal Justice. Also, he is the current Series Editor of the Wiley Series of Encyclopedias in Criminology \& Criminal Justice. An advocate of evidence-based practice, program fidelity, and research-practitioner partnership, he is a subject matter expert and a technical reviewer for NIJ, US BJA, OJJDP, NIDA, SAMSHA, NSF and several states agencies. His recent work has concentrated on implementing substance abuse and mental health treatment programs in underserved rural locations and related services delivery and outcome analysis. Currently, Dr. Miller is conducting mixed methods program evaluations of US Bureau of Justice Assistance Justice Mental Health initiatives in several states.

Alfred Blumstein is a University Professor and the J. Erik Jonsson Professor of Urban Systems and Operations Research emeritus and former Dean (from 1986 to 1993) at the H. John Heinz III College of Public Policy and Management of Carnegie Mellon University. He has had extensive experience in both research and policy with the criminal justice system since serving the President's Commission on Law Enforcement and Administration of Justice in 1966-67 as Director of its Task Force on Science and Technology. Dr. Blumstein was a member of the National Academy of Sciences Committee on Research on Law Enforcement and the Administration of Justice from its founding in 1975 until 1986. He served as Chairman of that Committee between 1979 and 1984, and has chaired the committee's panels on Research on Deterrent and Incapacitative Effects, on Sentencing Research, and on Research on Criminal Careers. He was a member of the Academy`s Commission on Behavioral and Social Sciences and Education from 1994-2000. In 1998, he was elected to membership in the National Academy of Engineering. His degrees from Cornell University include a Bachelor of Engineering Physics and a Ph.D. in Operations Research. He was awarded an honorary degree of Doctor of Laws by the John Jay College of Criminal Justice of the City University of New York. His research over the past thirty years has covered many aspects of criminal-justice phenomena and policy, including crime measurement, criminal careers, sentencing, deterrence and incapacitation, prison population, demographic trends, juvenile violence, and drug policy. 